\title{
雷撃写真像の画像解析
}

\begin{tabular}{|c|c|c|c|c|c|}
\hline 正員小島 & 章義 & (武藏工大) & 正員 堀井 & 慧 爾 & (豊田高専 \\
\hline 森 & 貴 & (武蔵工大) & 正員 中村 & 光 & (名古屋工大) \\
\hline & & (武) & 并 & & （武藏 \\
\hline
\end{tabular}

\section{Analysis of Lightning Channel by Image Processing}

Akiyoshi Kojima, Member, Yuki Nagamori, Associate, Hideo Mitsui, Member (Musashi Institute of Technology), Kenji Horii, Member (Toyota College of Technology), Kouichi Nakamura, Member (Nagoya Institute of Technology), Mototaka Sone, Member (Musashi Institute of Technology)

The pictures of lightning taken by a photo camera or a video camera give us important informations, such as the paths, the intensity and the falling point of lightning. It is necessary to change the analog data on pictures into digital ones, in order to analyze the information objectively. In this study, a CCD camera with a microcomputer is used to obtain digital image data. By using the digitalization, it is able to abstract the clear lightning channel path from the illegible picture by the new digital filter, and further it is possible to compare with the intensity distribution of each channel branch.

キーワード：雷放電, 雷チャネル, チャネル輝度, ディジタルフィルタ

\section{1. まえがき}

雷の機構解析の一手段として, 静止カメラによる写 真撮影やビデオカメラ, 流しカメラによる動的撮影が ある。雷の進展や雷撃は極めて速く，またその位置も 予想し難く，撮影された資料は貴重である。写真の撮 影により発光輝度や雷の形状, 落雷点の位置の標定な どを明らかにすることができ，他の測定法である電 流, 電位計測では解析できない情報を得ることがで きる。

しかし, 写真からの情報はアナログ像であるため, 結果の比較や表現に難がある。また，撮影㻴境やシャ ッ夕条件, 更には落雷時の強い発光などにより, 像は 必ずしも鮮明と注限らない。貴重な写真からできる限 り多くの客観的情報を抽出する工夫が必要である。

そこで著者らは, 写真解析のために画像処理技術の 導入を試みた。画像処理は写真のもつ輝度情報をディ ジタル化し,フィルタ処理による画像変換を行うこと ができる。例之ば，前述した悪条件下での不鮮明な放
電チャネルを明りよう化する新しいフィルタを工夫す ることにより，明りょうな画像にすることができる。 また, ディジタル化されたデータ，すなわちチャネル の輝度変化の情報, チャネル分岥での放電進展状況 や, 放電形態など, 写真による落雷解析への画像処理 の応用性を期待できる。

\section{2. ディジタルフィルタについて}

〈2・1〉 ディジタルフィルタ＼cjkstart不鮮明な画像をよ り明確な画像に変換するディジタルフィルタ処理とし ては，一般に輪郭強調処理が挙げられる。従来の輪郭 強調のアルゴリズムとしては，ラプラシアンフィル 夕，およびソベル法などが知られている。

ラプラシアンフィルタは隣接する画素の階調差が大 きい画素を強調し，画像中の線やエッジの部分だけを 高階調で表現するアルゴリズムで, 二次微分操作に相 当する変換である。フィルタは変換対象画素およびそ れに烸接する画素の階調值に重みを与え, その総和を 変換対象画素の階調值として与えるものである。変換 
対象画素およびそれに隣接する画素に与えられる重み は，以下のマトリックスが一般に用いられる。

$$
\left|\begin{array}{rrr}
0 & -1 & 0 \\
-1 & 4 & -1 \\
0 & -1 & 0
\end{array}\right|
$$

一方, ソベル法もまた隣接する画素の階調差を強調 する一次微分変換である。フィルタは変換対象画素お よびそれに隣接する画素の階調値に以下に示される重 みを与え, 縦方向と横方向のエッジ強調を与える。

$$
\Delta x:\left|\begin{array}{lll}
-1 & 0 & 1 \\
-2 & 0 & 2 \\
-1 & 0 & 1
\end{array}\right|
$$

$\Delta x:$ エッジの水平成分の強度

$$
\Delta y:\left|\begin{array}{rrr}
1 & 2 & 1 \\
0 & 0 & 0 \\
-1 & -2 & -1
\end{array}\right|
$$

$\triangle y:$ エッジの垂直成分の強度

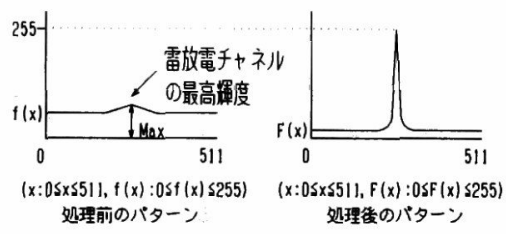

図 1 階調分布モデル図

Fig. 1. Distribution model of brightness after and before image processing.
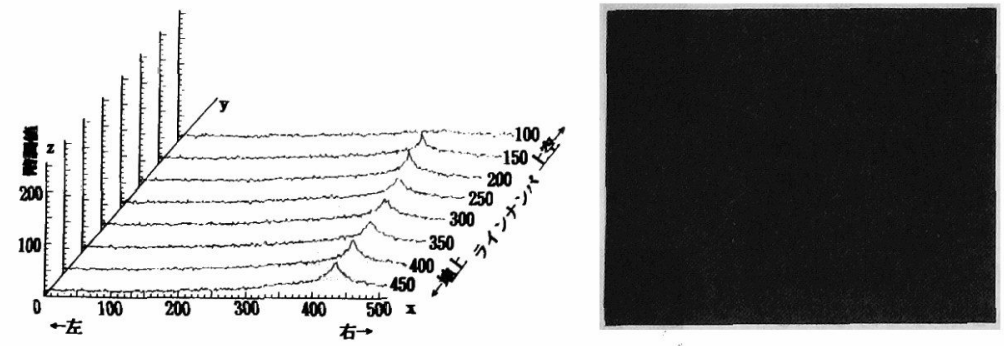

（b）ソペル法

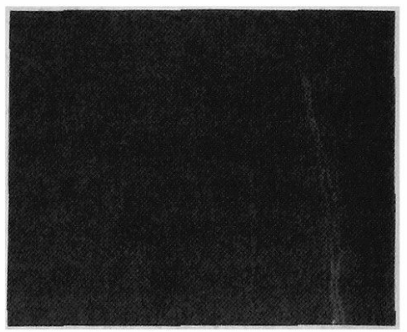

（c）ラプラシアン法

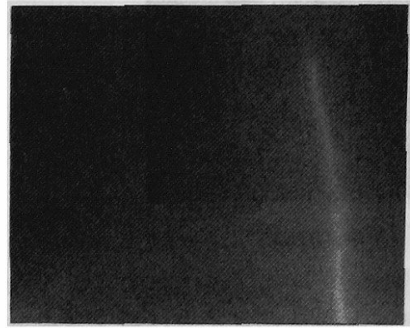

（a）原画像および三次元階調分布
〈2・2〉累乗強調処理 前記の既存のディジタル フィルタは, 後述するように必ずしも雷放電路に適し てはいない。そこで, 新しく, 雷放電画像のフィル夕 リングに対し有効なディジタルフィルタを工夫した。 以下そのアルゴリズムを述べる。 を中心にしたモデル図として図 1 に示される二等辺三 角形状としてモデル化する。この成分 $f(x)$ をもつ各 ドットに対して以下の強調関数を定義する。

$$
F(x)=\left(\frac{f(x)}{\operatorname{Max}}\right)^{N} \times 255
$$

$F(x)$ : 強調後の画素の階調, $f(x)$ : 強調前 の画素の階調, Max：注目の 1 ライン中で のチャネル最大階調

この関数は累乗関数であるため， $N$ の值を適切に 定めれば雷チャネル部(三角形頂点の近傍画素) はより 大きい階調値で表される。

\section{3. 目的とする画像への修正方法}

〈3・1〉霧, 雨, 雪などによりチャネルの不鮮明と なっている場合のチャネルの明りょう化 図 2 に各 ディジタルフィルタの効果が示される。(a )図に原画 像および 50 ラインおきの各ライン方向の階調分布を, (b )図にソベル法, (c )図にラプラシアン法, (d)図
雷チャネルは輝度の低い不鮮明な画像とし，放電路 
に累乗強調処理を施した画像を示す。(a)図より，原 画像のパターンの階調分布は雑音を含みながらなだら かに変化している。これに対し，（b 図のソベル法, (c) 図ラプラシアン法フィルタによる処理結果におい て, 両者とも, 視覚的に放電チャネルを確認すること は不可能である。この理由は, 階調の変化が雑音に対 し，緩やかであることによる。そのためチャネルの強 調の困難さにつながる。

一方, 累乗強調処理 $(\mathrm{d})$ 図の場合, チャネルが明確 化されており, チャネルの位置の確認を行うことがで きる。ただし, 強調処理により, 輝度は原情報を失っ てしまうため, 位置標定が行われた後, 原画像での輝 度を解析には用いる必要があることを付記する。この ように，天候による悪影響によりチャネルがほとんど 確認できない画像の場合, ソベル法, ラプラシアン法 によるチャネル強調は困難であるが，累乗強調処理は 有効な手段であることがわかる。

〈3・2〉 ハレーションを起こした雷画像のチャネル 抽出不鮮明画像を与える他の条件として, 落雷時 の強力な発光によるハーレションがあげられる。ハレ ーションによる画像輝度の“ぼけ”ばかりでなく, 写真 撮影時のシャッタブレやシャッ夕速度, あるいは露出 設定のミスによる画像の“ほけ”などはチャネル部分の 明確な観察に大きな障害となる。そこで前節と同様 に, ハレーションなどによってチャネルが不鮮明とな っている画像に対し強調処理を行った。

図 3 にハレーションを起こした雷画像の階調分布, そしてソベル法, ラプラシアン法, 累乗強調処理によ る処理結果をそれぞれ示す。人間の目には白色の広が りをもつ画像も，CCD カラによる 256 階調の識別 ではその輝度の差として表すことができる。（a）図に 示される階調分布は地上部のラインに近づくほど大き な山状の分布が現れている。このライン $350 〜 480$ の 領域がハレーションを起こしている部分である。しか し,これらの領域の分布にはピークが明らかに認めら れる。

このような画面に対し，（b 図のソベル法による処 理では, 画面下部(地上部)において(a)図からわかる ように，エッジが認められるため明りょう化される。 しかし, 上空部に移るにつれてなだらかな階調分布と なるため, 微分操作に有効となるエッジが認められな い。それゆえ, チャネルの明りょう化は行えない。ま た，(c)図に示されるラプラシアンフィル夕による処 理でも, 同様に“ぼけ”が生じチャネルの確認ができな い。一方, (d)図の累乗強調処理された画像は, ハレ ーションを起こしている領域にチャネルが強調され,

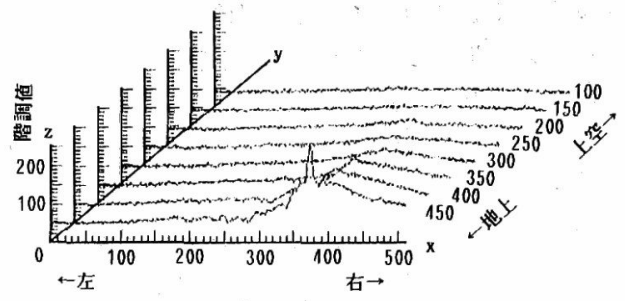

（a）ハレーションを起こした画像の三次元階調分布

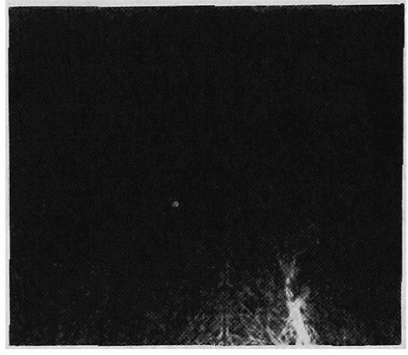

（b）ソベル法
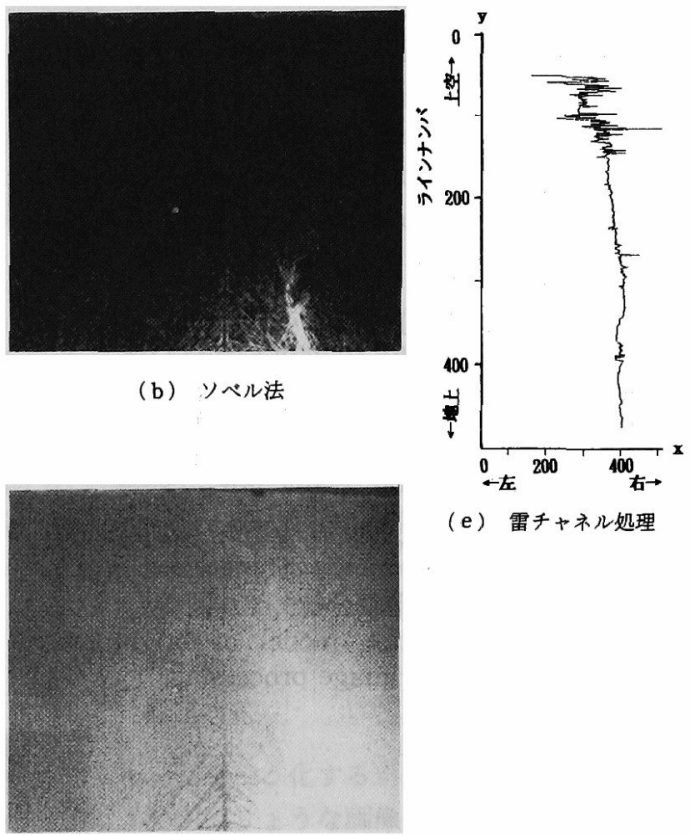

(e) 雷チャネル処理 (c) ラプラシアン法

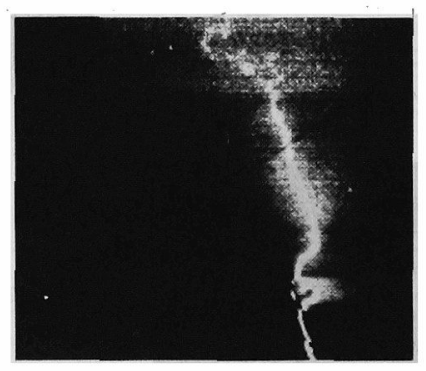

(d) 累乗強調処理

図 3 各種ディジタルフィルタによる ハレーションを起こした写真の チャネル強調画像

Fig. 3. Emphasized image by many digital filters for illegible picture with halation. 
視覚的に放電経路を判断できる。以上の比較より，累 乗強調処理がハレーションなどによる不鮮明な画像の キャネルの明りょう化に有効であることがわかる。

なお，チャネルの明りょう化により，チャネルの中 心位置の軌跡は, (e)図に $x-y$ 平面としてその結果 を示す。

\section{4. 画像からの情報抽出}

〈4・1〉チャネル軌跡, および輝度の推移特性の抽 出 前述した方法で, 雷撃写真よりチャネルの任意 の位置およびその輝度をディジタル量で表すことが可 能になったので，従来抽象的な解析しかできなかった 雷チャネルの軌跡および輝度特性を解析することがて きる。図 4 に原画像データの一例を三次元階調分布グ ラフとして示す。同図において, $x$ 軸好画面水平方向 (横方向)ラインのドット位置を表し,$y$ 軸は画面の垂 直方向(緥方向)へのラインナンバを表している。更 $k, z$ 軸は座標 $(x, y)$ のドットがもつ輝度を示してい る。

この分布において $x$ 軸， $y$ 軸のスケールは，それ ぞれ，写真における水平(左右)方向の距離，および垂 直方向の距離(高度)に対応することになる。すなわ ち，同分布においてラインナンバが小さい值であるほ ど，高度が大きいことを意味する。同図より各ライン の単一のピークが雷チャネルに相当し，チャネルは $x$ 軸济対して活潼直に分布している。また，その輝度 は上空に向かうに従い徐々に低下していくことがわか る。そこで同分布より得られる放電路の位置，および その階調の高さ方向に対する推移をグラフ化し図 5 に 示す。

(a)図は雷チャネル軌跡を示している。同図におい て, 縱軸には高度, 横軸には水平方向距離が示されてい る。なお同図の高度は，前述までラインナンバとして 表現されていたが，最高高度を“10”と規格化された値 を示す。雷解析においては雷雲直下，または雲中に最 高高度は位置すると思われるが，その確認ができない ため，本論文中では規格化された值を用いる。（a 図 において，放電チャネルは，水平方向(左右)に大きな “ブレ”はなく，垂直に立上っていることが示されてい る。一方，チャネルの高度に対する輝度の変化を(b) 図に示す。

同図において，上空部での雷チャネルの輝度と地上 部での輝度は大きく異なり, 高度に依存して上空部に なるに従い輝度は減少している。輝度の変化は電流の 成長や放電形態の違いを考慮するうえで重要となる。

しかし，他の雷放電と比較する目的から，地上部の

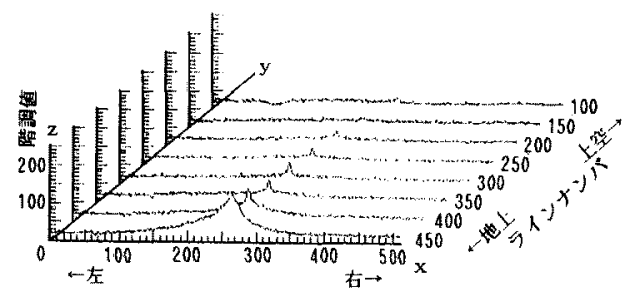

図 4 原画像データの階調分布の一例

Fig. 4. Brightness distribution of original lightning channel.

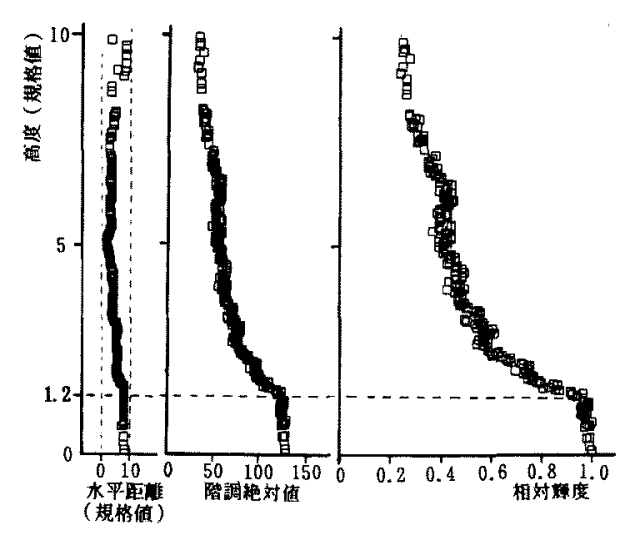

（a）雷チャネル（b）階調絶奶値 ○軌跡

(c) 相榇輝度

図 5 雷チャネル軌跡の階調絶対値抽よび 相対輝度

Fig. 5. Brightness distribution and relative intensity distribution on light of channel.

輝度を 1.0 として規格化し，(c)図にその特性を示 す。(a)図と (c) 図の比較により,地上より垂直に立 上っている領域, 高度 1.2 以下において輝度は飽和 し，この領域では大きな放電の変化はないことが示さ れている。また, 形状の用曲のある箇所の輝度は大き な隇衰を示している。

〈4・2〉チャネル分岐点での輝度推移特性 静止 写真による雷放電では, 放電チャネルは複数に分岐し ている場合が多い。分岐点には多くの雷解明に対する 情報が含まれている。例えば，どの枝放電が主放電 か, 電荷注入に対する各枝の役割などがあげられる。 ただし, 静止写真像においては時間的分解ができない ため，たとえ異なった時間に発生していても放電の経 路が同じであれば，見掛け上一つのチャネルとして解 析されることに留意すべきである。しかし，電流計や 電圧計その他の計測器では, 必ずしもこれらの情報の 提供には十分とは限らず，画像解析も一つの有効な解 
析手段となる。

そこで，チャネルが分岥している画像に対してチャ ネル軌跡，および輝度推移を求め, 分岐点前後での輝 度の增減状態の特性を解析する。例として，2 種類の 画像デー夕を取上げ，図6，図7にそれそれ示す。図・ 6(a)に示されるように，チャネル軌跡は高度10〜 7.5 の範囲において 3 本の枝が存在している。もしも 高度を実距離に置き換えることができれば，その枝分 れの位置や，雷雲との位置関係が議論できる。

一方, 雷の成長は電流密度の増加につながり, 輝度 に反映する。そこで地上輝度を 1.0 とした成長の過程 を(b)図に示す。(b)図において, 地上から続く雷千 ヤネルの輝度変化の連続性から，枝 1 が主放電路であ ることがわかる。枝2, 枝 3 の輝度は分跂点に执い て, 明らかに不連続性を示している。また各分岐の最

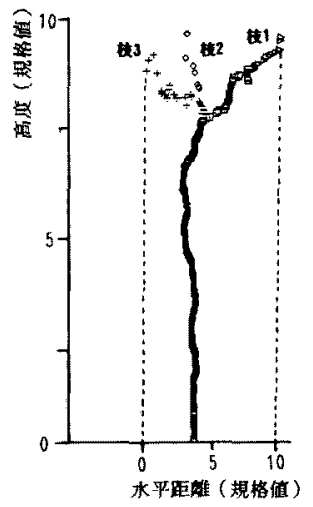

(a) 雷チャネル軌跡

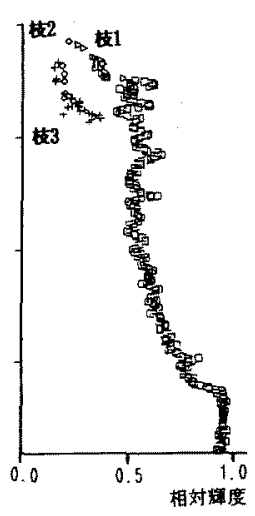

(b) 相対輝度
図 6 分岐点での輝度推移(例 1)

Fig. 6. Distribution of relative intensity at branches (example 1).

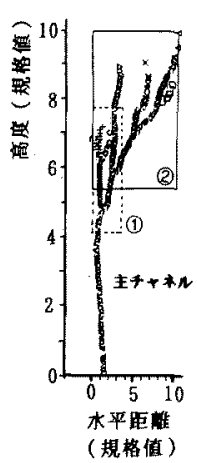

(a) チャ齐ル軌跡

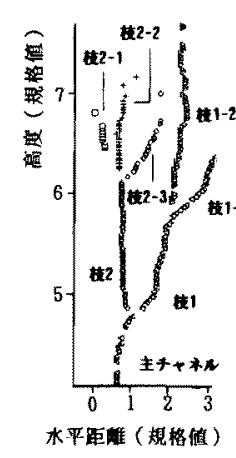

(b) 領域(1)拡大図
先端部の輝度は約 0.2 に収束している。なお,チャネ ルは位置に対し，わずかな振動を繰返して進行してい ることも，特徵の一つであることを付記する。一方， 他の一例のチャネル軌跡を図７に示す。(a)図に全経 路を示す。同図より, 高度 10〜5の範囲で複数に分肢 していることがわかる。そこで主チャネルと枝とを区 別するために図中(1)，(2)の領域を拡大して，それぞれ の枝チャネルの輝度特性を(b)，（c）図に示した。す なわち, (b)図は (a)図で示された(1)の領域(高度 $4 \sim 8$, 水平距離 $0 \sim 3$ )を示し, (c) 図は (a) 図で示さ れた(2)の領域(高度 5.5〜10, 水平距離 0〜10) を示し ている。なお，分割された各チャネルには番号が与え られている。領域(1)，すなわち(b)図における枝1， 枝 2 の輝度は主チャネルとの輝度の連続性より, 枝 1 が主チャネルとして判断できる。枝 2 は明らかに不連 続な值を示し，支流であることがわかる。更に支流 （枝 2) は上空部が，枝(2-1，2-2，2-3)の三つに分岐 されるが，それらの輝度は同一特性上に分布し，上空 部の放電が一つの集合であることがわかる。

同様に(c)図に扔いて，枝1-1と枝1-2に分れる が，輝度の分布から主たる経路は次のように認識さ れる。

$$
\text { 主チャネル 一伎 1 一枝 1-1 —枝 1-1-1 }
$$

\section{$\longrightarrow$ 枝 1-1-1-1}

以上, 例 1 , 例 2 の実画像加ら, 主チャネルの過程 を輝度分布から求めてみた。今後より多くの写真か ら，より多くの情報の取出しが可能となる。

$\langle 4 \cdot 3\rangle$ 落雷点の明りょう化 送電系統に机いて 鉄塔への落雷事故対策として，鉄塔への落雷点を認識 することは重要である。そこで，当強調アルゴリズム を応用することにより，鉄塔への落雷点を明らかにす

図 7 分岐点での輝度推移(例 2)

Fig. 7. Distribution of relative intensity at branches (example 2). 


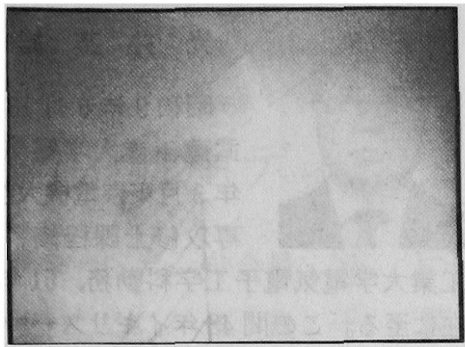

(a) 原画像

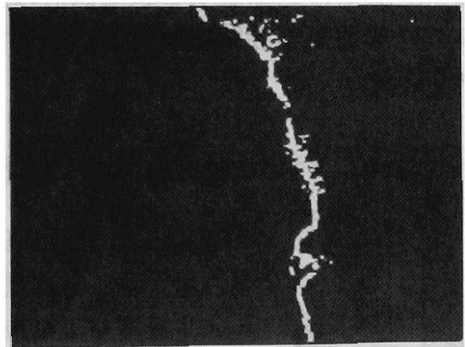

(c) チャネル二値化

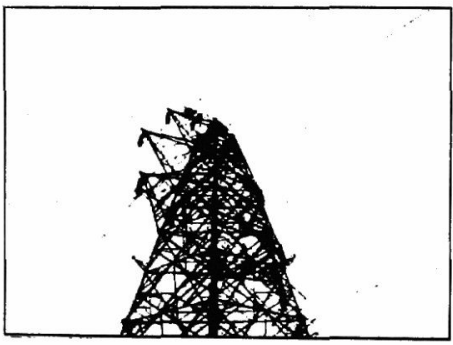

（b）鉄塔二值化

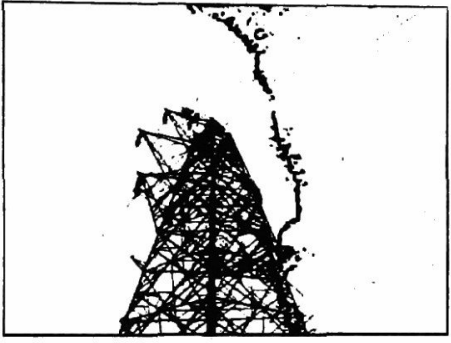

（d）合成画像

図 8 鉄塔落雷点の明りょう化(試料 1)

Fig. 8. Composite steel image for tower and lightning channel (sample 1).

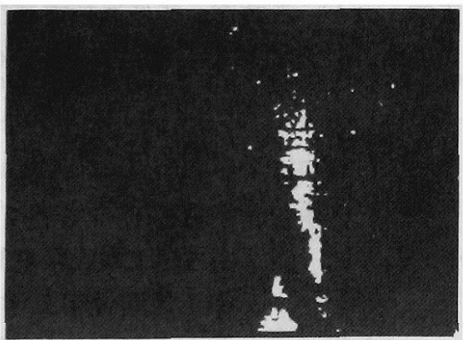

(a) チャネル二值化

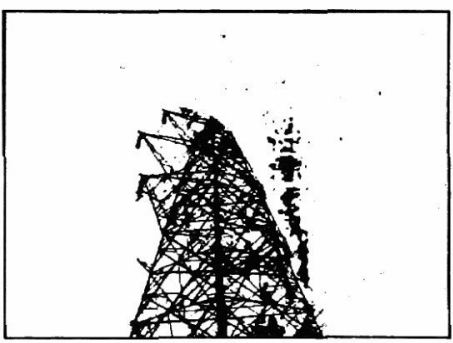

(b) 合成画像

図 9 鉄塔落雷点の明りょう化(試料 2)

Fig. 9. Composite steel image for tower and lightning channel (sample 2).

る。図 8(a ) にある落雷時の写真を示す。同図は, 上 空部での雷チャネルの輝度が薄く, 肉眼では確認しに くい。また, 落雷点は強い発光のためハレーションを 生じ，同様に観測不可能である。

鉄塔への落雷点を明らかにするためには，鉄塔の情 報および雷チャネルの情報が必要となる。後者は当強 調アルゴリズムを応用することにより得ることが可能 であるが, 前者は落雷時の写真から得ることはほほ不 可能である。そこで, 昼間同一アングルで撮影される 鉄塔写真との画像合成を行う。合成を行う一つの方法 としてチャネルのみの画像, 鉄塔のみの画像をそれぞ れ二值化し合成する。（b)図は昼間撮影される鉄塔写
真画像をその階調値に応じて白画素，黒画素のみに二 值化したものである。一方，（c）図は当強調アルゴリ ズムで処理された不明りょう画像を二值化した写真で ある。それに対し $(\mathrm{d})$ 図は両者の情報を合成した画像 である。同図より，不明りょうで確認不可能であった 鉄塔とチャネルの位置関係が明らかとなり, 落雷点が 明りょう化される。

同様に他の落雷写真に関して図 9 に示す。(a)図に 示されるチャネル画像と, 図 8 (b)の鉄塔画像を合成 することにより，図 9(b)が得られる。このように， 画像処理を用いることにより鉄塔への落雷点を明りょ う化することができる。 


\section{5. むす び}

画像処理を雷の撮影された写真に応用することによ って以下に示されることが明らかにされた。

（1）ディジタルフィルタの一種である累乗強調処 理は, 霧, 雨, 雪などの気象条件下で撮影されるチャ ネルが不明りょうな画像に対し有効である。従来のデ イジタルフィルタであるソベル法およびラプラシアン 法では, チャネル明りょう化は行うことはできない。 またハレーション画像に対しても, 同様に極めて有効 である。これにより従来解析不可能であった不明りょ うな写真のチャネル形状や鉄塔への落雷点の議論が可 能となった。

（2）画像処理技術の導入により, 雷チャネルの輝 度の推移が客観的なディジタルデータとして把握で き, チャネル分岐点での放電進展状況, 放電進展形態 などの解析への応用の可能性が示された。

このような解析手法により得られる情報を, 今後雷 研究の分野に提供することにより, 雷解析のいっそう の発展を促せればよいと考えている。

本論文の作成にあたり, 多大な協力をしていただい た, 電気学会東海支部「高度情報化時代の雷研究」の 若手セミナーに関連された方々に深く感謝いたしま す。また, 日ごろから本研究を支援して下さった武蔵 工業大学高電圧研究室久保山洋一氏に深く感謝いた します。

(平成 2 年 5 月 28 日受付, 同 3 年 5 月 2 日再受付)

\section{文献}

（1）榎本：画像の情報処理，コロナ社

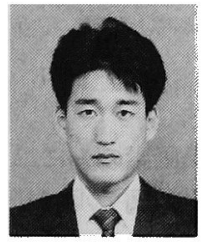

\section{小島 章 義 (正員)}

昭和 40 年 4 月 25 日生。平成 3 年 3 月武藏工業大学大学院電気工学専 攻修士課程修了。同年 4 月日本石油 (株) 入社。現在, 中央技術研究所に おいて, 炭素瀻維の研究・開発に従事。

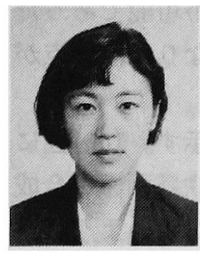

\section{長 森 由 貴 (准員)}

昭和 41 年 7 月 31 日生。平成 2 年 3 月武蔵工業大学工学部電気電子工 学科卒業。同年 4 月同大学大学院電 気工学専攻修士課程進学, 現在に至 る。主として, 高速演算, 雷写真の画像解析に関する 研究に従事。

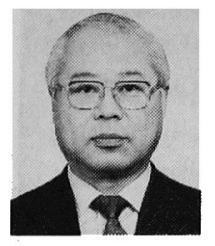

\section{光 井 英 雄 (正員)}

昭和 9 年 6 月 13 日生。 32 年 3 月 武蔵工業大学電気工学科卒業。 38 年 3 月東京電機大学大学院電気工学 専攻修士課程修了。32 年 4 月武蔵 工業大学電気電子工学科勤務, 51 年 4 月同教授, 現 在に至る。この間 48 年イギリス・サルフォード大学に 客員研究員として 1 年間赴任。工学博士。主として, 電気絶緑物の絶緑破壊と放電機構に関する研究に従 事。 47 年電気学会論文賞受賞。真空協会, 電気設備 学会会員。

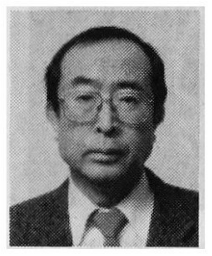

\section{堀 井 憲 爾 (正員)}

昭和 5 年 1 月 7 日生。 27 年 3 月 名古屋大学工学部電気学科卒業。同 年 4 月通産省工業技術院電気試験所 (現, 電子技術総合研究所) 入所, 高 電圧現象, 高エネルギー研究室長。 46 年 4 月名古屋 大学工学部教授。平成 2 年 10 月豊田工業高等専門学 校校長。工学博士。電力工学, 電力応用工学, 高電圧 工学, ロケット誘雷, 極低温超電導工学に関する研究 に従事。 61 年電気学会電力賞受賞。CIGRE 会員。

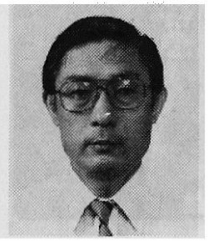

$$
\text { 中 村 光 一 (正員) }
$$

昭和 17 年 3 月 7 日生。 41 年 3 月 名古屋工業大学電気工学科卒業。 42 年 4 月同大学工学部電気工学科助 手, 55 年同工学部講師, 63 年同助 教授, 現在に至る。工学博士。系統解析, ロケット誘 雷, 高温超電導の電力応用などに関する研究に従事。 57 年電気学会論文賞, 平成 2 年同進歩賞受賞。IEEE 会員。

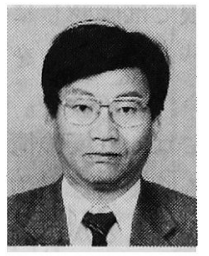

\section{曽 神 元 隆 (正員)}

昭和 17 年 1 月 12 日生。 43 年 3 月武蔵工業大学大学院電気工学専攻 修士課程修了。 40 年 4 月同大学電 気電子工学科勤務, 平成 2 年 4 月同 教授, 現在に至る。この間 59 年アメリカ・クラークソ ン大学に客員研究員として 1 年間赴任。工学博士。主 として, 有機絶縁材料の絶縁破壊機構および気中放電 現象に関する研究に従事。 47 年電気学会論文賞受賞。 電子情報通信学会会員。 